\title{
Pengaruh Pemberian Cod Liver Oil pada Pakan Komersial terhadap Kolesterol, Low Density Lipoprotein (LDL) dan High Density Lipoprotein (HDL) pada Daging Udang Galah (Macrobrachium rosenbergii).
}

\section{Effect of Cod Liver Oil in the Commercial Feed Cholesterol, Low Density Lipoprotein (LDL) and High Density Lipoprotein (HDL) on Meat Fresh Water Prawns (Macrobrachium rosenbergii).}

\author{
Mega Fitria Ardiany ${ }^{1 *}$, Agustono ${ }^{2}$, dan Boedi Setya Rahardja ${ }^{2}$ \\ ${ }^{1}$ Budidaya Perairan, Fakultas Perikanan dan Kelautan Universitas Airlangga, Surabaya 60115 \\ ${ }^{2}$ Manajemen Kesehatan Ikan \& Budidaya Perairan, Fakultas Perikanan dan Kelautan Universitas Airlangga, \\ Surabaya 60115 \\ *megafitria91@yahoo.com
}

\begin{abstract}
Abstrak
Udang galah merupakan komoditas ikan air tawar yang bernilai ekonomis, khususnya di Indonesia. Seiring berkembangnya pariwisata dan beragam kuliner konsumsi udang galah di Indonesia meningkat dan peluang ekspor udang galah terbuka. Udang galah mengandung kolesterol yang tinggi yaitu 385,03 mg/dl. Kolesterol dalam tubuh yang berlebihan akan menimbulkan suatu kondisi yang disebut aterosklerosis kondisi ini merupakan cikal bakal terjadinya penyakit jantung dan stroke. Salah satu upaya yang harus dilakukan untuk menghasilkan produk budidaya yang rendah kolesterol adalah melalui rekayasa pakan dengan penambahan suplementasi asam lemak yang berasal dari dari organisme laut. Melalui suplementasi asam lemak, maka diharapkan kadar trigliserida dan kolesterol low density lipoprotein (LDL) akan turun sehingga dapat meningkatkan kadar kolestrol high density lipoprotein (HDL). Penelitian ini bertujuan untuk menurunkan kolesterol, low density lipoprotein (LDL) dan meningkatkan kadar kolesterol high density lipoprotein (HDL) daging udang galah. Penelitian ini menggunakan metode eksperimental dengan Rancangan Acak lengkap yang terdiri dari lima perlakuan, empat kali ulangan. Analisis data menggunakan uji statistik sidik ragam Analysis of Variant (ANOVA). Apabila ada perbedaan antar perlakuan dilanjutkan dengan Uji Jarak Berganda Duncan untuk mengetahui perlakuan yang paling baik. Hasil perhitungan Analysis of Variant (ANOVA) menunjukan adanya perbedaan yang nyata $(\mathrm{p}<0,05)$. Parameter utama kolestrol total, kadar kolesterol high density lipoprotein (HDL) dan low density lipoprotein (LDL) daging udang galah yang diujikan di Laboratorium Faal, Fakultas Kedokteran, Universitas Brawijaya. Parameter pendukung yang diamati yaitu kualitas air pemeliharaan udang galah. Pemberian cod liver oil pada dosis $12 \%$ dapat menurunkan kolesterol total dengan kadar terendah dari perlakuan lainnya dengan rata-rata 88,3125 mg/dl. Pemberian cod liver oil pada dosis $12 \%$ dapat menurunkan low density lipoprotein (LDL) kadar terendah dari perlakuan lainnya dengan rata-rata $197,72 \mathrm{mg} / \mathrm{dl}$. Pemberian cod liver oil pada dosis $12 \%$ dapat menaikkan high density lipoprotein (HDL) kadar tertinggi dari perlakuan lainnya dengan rata-rata 128,84 mg/dl.
\end{abstract}

Kata Kunci : Kolesterol, Low density lipoprotein (LDL), High density lipoprotein (HDL)

\begin{abstract}
Fresh water prawns are commodities freshwater fish that have economic value, particularly in Indonesia. As the development of tourism and a variety of culinary consumption in Indonesia fresh water prawns and open export opportunities. Fresh water prawns, high cholesterol is 385,03 $\mathrm{mg} / \mathrm{dl}$. Excessive cholesterol in the body will lead to a condition called atherosclerosis condition is the forerunner of heart disease and stroke. One of the efforts that must be undertaken to produce low cholesterol aquaculture products are engineered feed, supplementation with fatty acids derived from marine organisms. Through the fatty acid supplementation, it is expected that the levels of triglycerides and low density lipoprotein cholesterol (LDL) will decline so it can raise levels of high density lipoprotein cholesterol (HDL). Analysis of data using statistical test of Variant Analysis of variance (ANOVA) to determine the effect of treatment. If there are differences among the treatments continued with Duncan Multiple Range Test to determine the best treatment. Analysis of Variant (ANOVA) result a significant difference $(p<0,05)$. The main parameters of total cholesterol, high density lipoprotein cholesterol (HDL) and low density lipoprotein (LDL) meat prawns tested at the Laboratory of Physiology, Faculty of Medicine, Universitas Brawijaya. Parameter supporters observed that the maintenance of water quality fresh water prawns. Provision of cod liver oil at a dose of $12 \%$ can lower total cholesterol with the lowest levels of the other treatments,
\end{abstract}


with an average of $88.3125 \mathrm{mg} / \mathrm{dl}$. Provision of cod liver oil at a dose of $12 \%$ can reduce low density lipoprotein (LDL) levels were lowest from other treatments with an average of $197.72 \mathrm{mg} / \mathrm{dl}$. Provision of cod liver oil at a dose of $12 \%$ can increase high density lipoprotein $(H D L)$ levels were highest from other treatments with an average of $128.84 \mathrm{mg} / \mathrm{dl}$.

Keywords : Cholesterol, Low density lipoprotein $(L D L)$, High density lipoprotein $(H D L)$

PENDAHULUAN

Udang galah merupakan komoditas ikan air tawar yang bernilai ekonomis, khususnya di Indonesia. Seiring berkembangnya pariwisata dan beragam kuliner udang galah di Indonesia, minat masyarakat untuk mengonsumsi udang galah semakin meningkat (Direktorat Jenderal Perikanan Budidaya, 2015). Udang galah mengandung kolesterol tinggi yaitu 385,03 mg/dl (Lab Faal, Universitas Brawijaya, 2016). Menurut LIPI Pangan dan Kesehatan (2009) kolesterol dalam tubuh yang berlebihan akan tertimbun di dalam dinding pembuluh darah dan menimbulkan suatu kondisi yang disebut aterosklerosis yaitu penyempitan atau pengerasan pembuluh darah. Kondisi ini merupakan cikal bakal terjadinya penyakit jantung dan stroke.

Salah satu upaya yang dapat dilakukan untuk menghasilkan produk budidaya yang memiliki kandungan kolesterol rendah adalah melalui rekayasa budidaya antara lain melalui rekayasa pemberian pakan, dengan penambahan suplementasi asam lemak yang berasal dari organisme laut. Melalui suplementasi asam lemak, maka diharapkan kadar trigliserida dan kolesterol low density lipoprotein
(LDL) akan turun sehingga dapat meningkatkan kadar kolestrol high density lipoprotein (HDL) dan apolipoprotein $\mathrm{E}$ sampai $71 \%$ (Emken et al., 1999). Sukarsa (2004) mengemukakan bahwa asam lemak omega-3 dapat menurunkan kadar kolestrol dalam darah, dengan cara menghambat pembentukan protein dan trigliserida dalam very low density lipoprotein (VLDL) sehingga kolesterol menjadi rendah.

\section{METODOLOGI PENELITIAN}

\section{Tempat dan Waktu Penelitian}

Penelitian pakan dilaksanakan di Unit Pengelola Perikanan Budidaya (UPPB) Prigi, Trenggalek, Jawa Timur pada bulan Juni 2016.

\section{Alat dan Bahan}

Alat dan bahan yang digunakan dalam penelitian ini adalah 20 buah

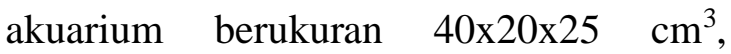
aerator, selang aerasi, selang sipon, batu aerasi, bak plastik besar, gelas ukur, timbangan digital, $\mathrm{pH}$ meter, DO meter dan amonia test kit. Bahan utama yang digunakan dalam penelitian adalah udang galah (Macrobrachium rosenbergii) dengan berat 10 gram. Udang galah didapatkan dari Unit Pengelola Perikanan Budidaya (UPPB) Prigi, Trenggalek, Jawa 
Timur. Bahan yang digunakan antara lain cod liver oil (CLO) merk baby's DHA, pakan komersial merk Feng Li, klorin.

\section{Prosedur kerja}

\section{A. Persiapan Pemeliharaan Udang}

\section{Galah (Macrobrachium rosenbergii)}

Tahap awal dalam melakukan persiapan yaitu menyiapkan akuarium yang akan digunakan dengan ukuran $40 \times 20 \times 25$ $\mathrm{cm}^{3}$. Udang galah sebanyak 140 ekor yang telah diukur panjang dan berat tubuhnya ditebar ke dalam akuarium dengan kepadatan 7 ekor/ akuarium serta diberi aerasi.

\section{B. Penyediaan Pakan Udang Galah (Macrobrachium rosenbergii)}

Pakan yang diberikan untuk udang galah berupa pakan komersial merk Feng Li yang ditambahkan cod liver oil dan tepung tapioka sebagai perekat. Semua bahan penyusun pakan disiapkan dan ditimbang sesuai dosis yang ditentukan. Pakan komersial kemudian ditambahkan cod liver oil serta dicampurkan dengan tepung tapioka yang dilarutkan air hangat. Bahan tersebut diaduk hingga adonan menjadi tercampur. Bahan yang telah tercampur dicetak kembali menjadi bentuk pelet. Pakan di oven dengan suhu $50^{\circ} \mathrm{C}$ selama 24 jam. Tujuan pengovenan yaitu untuk mengurangi kadar air serta menambah daya simpan pakan. Pakan yang sudah jadi kemudian dihitung di analisa proksimat yang bertujuan untuk mengetahui kandungan nutrisi pakan. Komposisi nutrisi pakan pada perlakuan Tabel 1.

Tabel 1. Kandungan pakan Feng Li

\begin{tabular}{lc}
\hline \multicolumn{1}{c}{ Kandungan } & $\begin{array}{c}\text { Pakan Komersial } \\
(\%)\end{array}$ \\
\hline Bahan kering & $89 \%$ \\
Abu & $13 \%$ \\
Protein & $40 \%$ \\
Lemak kasar & $5 \%$ \\
Serat kasar & $2 \%$ \\
Bahan ekstrak & tanpa \\
nitrogen (BETN) & $29 \%$ \\
Air & \\
\hline
\end{tabular}

Sumber : Komposisi pakan Feng Li pada kemasan pakan

Analisa proksimat dari tepung tapioka berdasarkan Puspitasari (2015) dan dapat dilihat pada tabel 2 .

Tabel 2. Analisa proksimat tepung tapioka

\begin{tabular}{lc}
\hline \multicolumn{1}{c}{ Kandungan } & $\begin{array}{c}\text { Tepung Tapioka } \\
(\%)\end{array}$ \\
\hline Bahan kering & $87,692 \%$ \\
Abu & $1,243 \%$ \\
Protein kasar & $1,748 \%$ \\
Lemak kasar & $0,473 \%$ \\
Serat kasar & $2,744 \%$ \\
Bahan Ekstrak & Tanpa \\
Nitrogen (BETN) & $93,794 \%$ \\
\hline
\end{tabular}

Sumber : Puspitasari (2015)

Analisa proksimat dari cod liver oil berdasarkan dari Faradilah (2015) dapat dilihat pada tabel 3 .

Tabel 3. Analisa proksimat cod liver oil

\begin{tabular}{lc}
\hline \multicolumn{1}{c}{ Kandungan } & $\begin{array}{c}\text { Tepung Tapioka } \\
(\%)\end{array}$ \\
\hline Bahan kering & $95,9502 \%$ \\
Abu & $0 \%$ \\
Protein kasar & $0 \%$ \\
Lemak kasar & $94,3023 \%$ \\
Serat kasar & $0 \%$ \\
Bahan Ekstrak Tanpa & $0 \%$ \\
Nitrogen (BETN) & \\
Sumber: Faradilah (2015) &
\end{tabular}


Tabel 4. Komposisi nutrisi pakan pada perlakuan

\begin{tabular}{lccccc}
\hline Komposisi (\%) & \multicolumn{5}{c}{ Perlakuan } \\
\cline { 2 - 6 } & P0 & P1 & P2 & P3 & P4 \\
\hline Pakan komersial & 100 & 100 & 100 & 100 & 100 \\
Tepung tapioka & 2 & 2 & 2 & 2 & 2 \\
Cod liver oil & 0 & 3 & 6 & 9 & 12 \\
TOTAL & $\mathbf{1 0 2}$ & $\mathbf{1 0 5}$ & $\mathbf{1 0 8}$ & $\mathbf{1 1 1}$ & $\mathbf{1 1 4}$ \\
Bahan Kering & 90,75384 & 93,632346 & 96,510852 & 99,389358 & 102,267864 \\
Abu & 13,02486 & 13,02486 & 13,02486 & 13,02486 & 13,02486 \\
Protein Kasar & 40,03496 & 40,03496 & 40,03496 & 40,03496 & 40,03496 \\
Lemak Kasar & 5,00946 & 7,838529 & 10,667598 & 13,496667 & 16,325736 \\
Serat Kasar & 2,05488 & 2,05488 & 2,05488 & 2,05488 & 2,05488 \\
BETN & 30,87588 & 30,87588 & 30,87588 & 30,87588 & 30,87588 \\
\hline
\end{tabular}

Sumber : Hasil perhitungan manual

\section{Pemberian Pakan Udang Galah (Macrobrachium rosenbergii)}

Pengaturan pakan diberikan dengan berat $5 \%$ dari total biomasa pemberian pakan sebanyak dua kali dalam sehari yaitu pukul 16.00 dan 22.00 WIB. Dosis pakan yang diberikan yaitu $40 \%$ pada pukul 16.00 WIB, dan $60 \%$ pada pukul 22.00.

\section{Parameter Penelitian}

Parameter utama dalam penelitian ini adalah pengaruh kadar kolestrol, low density lipoprotein (LDL) dan high density lipoprotein (HDL) dalam daging udang galah yang diujikan di Laboratorium Faal, Fakultas Kedokteran, Universitas Brawijaya Malang. Parameter pendukung yang diamati yaitu parameter kualitas air seperti, suhu, DO, pH dan amonia.

\section{Analisis Data}

Data yang diperoleh dianalisis dengan menggunakan uji statistik ANOVA
(Analisis of Variance) untuk mengetahui apakah ada perbedaan antar perlakuan, kemudian dilanjutkan dengan Uji Jarak Berganda Duncan (Duncan's Multiple Range Test) dengan taraf nyata 5\% untuk mengetahui perlakuan yang terbaik (Kusriningrum, 2008).

\section{HASIL DAN PEMBAHASAN}

\section{Kolesterol Total Udang Galah}

Data rata-rata kolesterol total daging udang galah dapat dilihat pada Tabel 5.

Tabel 5. Rata-rata kolesterol total daging udang galah ((Macrobrachium rosenbergii)

\begin{tabular}{lc}
\hline \multicolumn{1}{c}{ Perlakuan } & \multicolumn{1}{c}{ Kolesterol $(\mathbf{m g} / \mathbf{d l})$} \\
\hline $\mathrm{P} 0($ Cod liver oil $0 \%)$ & $385,03^{\mathrm{a}} \mathrm{mg} / \mathrm{dl} \pm 42,69$ \\
$\mathrm{P} 1($ Cod liver oil $3 \%)$ & $307,30^{\mathrm{b}} \mathrm{mg} / \mathrm{dl} \pm 5.78$ \\
$\mathrm{P} 2($ Cod liver oil $6 \%)$ & $228,90^{\mathrm{c}} \mathrm{mg} / \mathrm{dl} \pm 10,65$ \\
$\mathrm{P} 3($ Cod liver oil $9 \%)$ & $161,91^{\mathrm{d}} \mathrm{mg} / \mathrm{dl} \pm 55,79$ \\
$\mathrm{P} 4($ Cod liver oil $12 \%)$ & $88,31^{\mathrm{e}} \mathrm{mg} / \mathrm{dl} \pm 34,72$ \\
\hline
\end{tabular}

Keterangan : Superskrip yang berbeda pada kolom yang sama menunjukkan terdapat perbedaan yang nyata $(\mathrm{P}<0,05)$

$$
\text { Berdasarkan penelitian pada }
$$
kolesterol udang galah (Macrobrachium rosenbergii) diperoleh hasil kolesterol total 
berkisar antara 88,31 mg/ dl 385,03 mg/dl. Rata-rata kolesterol menunjukan adanya perbedaan yang nyata antara perlakuan $\mathrm{P} 0$ (CLO 0\%), P1 (CLO 3\%), P2 (CLO 6\%), P3 (CLO 9\%) dan P4 (CLO 12\%). Kadar kolesterol terendah didapatkan pada perlakuan P4 (CLO 12\%) yaitu 88,3125 $\mathrm{mg} / \mathrm{dl}$. Kadar kolesterol tertinggi didapatkan pada perlakuan P0 (CLO 0\%) dengan kadar kolesterol total udang galah $385,03 \mathrm{mg} / \mathrm{dl}$.

Penurunan kolesterol pada udang galah diduga dipengaruhi oleh penyerapan makanan yang telah di makan udang galah. Hal ini sesuai dengan pernyataan Ceccaldi (1989) bahwa saluran pencernaan bertanggung jawab bagi banyak hewan dan krustasea khususnya untuk fungsi gizi. Penyerapan nutrisi makanan dimulai dalam mulut yang kemudian dilanjutkan ke kerongkongan dan menuju ke saluran pencernaan. Makanan kemudian diserap oleh saluran pencernaan yaitu hepatopankreas atau kelenjar midgut. Hepatopankreas merupakan organ utama yang digunakan untuk fungsi metabolisme, sintesis dan sekresi enzim pencernaan, penyerapan produk makanan dicerna.

Mekanisme penurunan kolesterol lainnya diduga disebabkan pengaruh asam lemak omega 3 terhadap lipoprotein. Hal ini sesuai dengan pernyataan Sukarsa (2004) bahwa manfaat dari asam lemak omega-3 dalam menurunkan kadar kolesterol darah disebabkan pengaruhnya terhadap mekanisme produksi lipoprotein transport dalam hati yang disekresikan ke dalam darah. Arifah (2006) menambahkan bahwa lipoprotein yang pertama kali berperan dalam pengangkutan lipid dari makanan adalah kilomikron. Kilomikron menghidrolisis triasligliserol oleh lipase lipoprotein kemudian diubah menjadi diasligliserol, yang selanjutnya menjadi monoasligliserol dan akhirnya menjadi asam lemak bebas dan gliserol. Sukarsa (2004) berpendapat bahwa asam lemak omega-3 dapat menurunkan kadar kolesterol dalam darah, dengan cara menghambat pembentukan trigliserida dalam very low density lipoprotein (VLDL) sehingga kolesterol menjadi rendah.

Penurunan kolesterol juga dipengaruhi oleh asam lemak tidak jenuh yang dapat menurunkan LDL sehingga kolesterol menurun. Hal ini sesuai dengan pernyataan Emken et al. (1999) bahwa asam lemak tidak jenuh khususnya omega3 dapat menghambat sintesa VLDL yang mengakibatkan produksi LDL akan berkurang. Melalui suplementasi asam lemak, maka kadar trigliserida dan kolesterol low density lipoprotein (LDL) akan turun dan dapat meningkatkan kadar kolesterol high density lipoprotein (HDL). Sukarsa (2004) juga menambahkan bahwa HDL akan mengangkut kolesterol ke dalam hati selanjutnya dipecah menjadi asam 
empedu dan dibuang melalui ekskresi tubuh.

\section{Kolesterol Low Density Lipoprotein (LDL)}

Hasil perhitungan kolesterol low density lipoprotein (LDL) pada daging udang galah (Macrobrachium rosenbergii) didapatkan kisaran kolesterol LDL pada daging udang galah dengan rata-rata 197,72 $\mathrm{mg} / \mathrm{dl}-390,5625 \mathrm{mg} / \mathrm{dl}$. Data rata-rata kolesterol LDL terdapat pada Tabel 6.

Tabel 6. Rata-rata kadar low density lipoprotein (LDL) daging udang galah ((Macrobrachium rosenbergii

\begin{tabular}{ll}
\hline \multicolumn{1}{c}{ Perlakuan } & Kolesterol LDL (mg/dl) \\
\hline P0 $($ Cod liver oil 0 \%) & $390,56^{\mathrm{a}} \mathrm{mg} / \mathrm{dl} \pm 37,086$ \\
$\mathrm{P} 1($ Cod liver oil $3 \%)$ & $349,58^{\mathrm{a}} \mathrm{mg} / \mathrm{dl} \pm 31,017$ \\
$\mathrm{P} 2($ Cod liver oil $6 \%)$ & $367,44^{\mathrm{a}} \mathrm{mg} / \mathrm{dl} \pm 26,921$ \\
$\mathrm{P} 3($ Cod liver oil $9 \%)$ & $334,62^{\mathrm{a}} \mathrm{mg} / \mathrm{dl} \pm 61,057$ \\
P4 (Cod liver oil 12 \%) & $197,72^{\mathrm{b}} \mathrm{mg} / \mathrm{dl} \pm 2,174$ \\
\hline Keterangan : Superskrip yang berbeda pada kolom \\
yang sama menunjukkan terdapat perbedaan yang \\
nyata $(\mathrm{P}<0,05)$
\end{tabular}

Perlakuan P4 (CLO 12\%) berbeda nyata dengan perlakuan PO (CLO 0\%), P1 (CLO 3\%), P2 (CLO 6\%) dan P3 (CLO 9\%). Penurunan LDL pada daging udang galah diduga disebabkan pengaruh cod liver oil yang mengandung omega-3 sebesar 21,993\% yang mempengaruhi kerja LDL dan VLDL. Hal ini sesuai dengan pernyataan Fernandez and West (2005) bahwa mekanisme penurunan LDL dengan omega-3 (PUFA) dalam menurunkan LDL melalui metabolisme VLDL dengan mengurangi trigliserida plasma (TG). Menurut Ramprasath et al. (2012) omega-3 (PUFA) telah terbukti mengurangi trigliserida melalui penghambatan diasilgliserol. Pengurangan trigliserida melalui lipoprotein yang kaya trigliserida (TRL) dan melalui pengurangan tingkat konsentrasi apoB-100. Stancu and Sima (2001) menambahkan bahwa penurunan LDL diduga disebabkan peningkatan reseptor LDL di hati. Reseptor LDL yang menentukan pengurangan beredarnya LDL dan prekursornya yaitu intermediet density lipoprotein (IDL) dan VLDL.

\section{Kolesterol High Density Lipoprotein (HDL)}

Hasil perhitungan kolesterol high density lipoprotein (HDL) pada daging udang galah (Macrobrachium rosenbergii) didapatkan kisaran kolesterol HDL pada daging udang galah yaitu 38,69-128,84 $\mathrm{mg} / \mathrm{dl}$. Data rata-rata kolesterol HDL terdapat pada Tabel 7.

Tabel 7. Rata-rata nilai high density lipoprotein (HDL) daging udang galah (Macrobrachium rosenbergii)

\begin{tabular}{cl}
\hline Perlakuan & \multicolumn{1}{c}{ Kolesterol HDL } \\
\hline P0 $($ Cod liver oil 0 \%) & $38,69^{\mathrm{c}} \mathrm{mg} / \mathrm{dl} \pm 3,076$ \\
P1 (Cod liver oil 3 \%) & $53,19^{\mathrm{bc}} \mathrm{mg} / \mathrm{dl} \pm 15,682$ \\
P2 $($ Cod liver oil $6 \%)$ & $53,26^{\mathrm{bc}} \mathrm{mg} / \mathrm{dl} \pm 17,543$ \\
P3 (Cod liver oil $9 \%)$ & $68,16^{\mathrm{b}} \mathrm{mg} / \mathrm{dl} \pm 32,667$ \\
P4 (Cod liver oil $12 \%)$ & $128,84^{\mathrm{a}} \mathrm{mg} / \mathrm{dl} \pm 3,539$ \\
\hline
\end{tabular}

Keterangan : Superskrip yang berbeda pada kolom yang sama menunjukkan terdapat perbedaan yang nyata $(\mathrm{P}<0,05)$

Peningkatan HDL pada daging udang galah dipengaruhi oleh suplementasi omega-3. Hal ini sesuai dengan pernyataan Drevon (2009) bahwa metabolisme lipoprotein dengan suplementasi asam lemak omega-3 menyebabkan peningkatan 
kecil dalam konsentrasi plasma kolesterol HDL. Peningkatan HDL terjadi bersamaan dengan menurunnya konsentrasi plasma VLDL. Peningkatkan konsentrasi HDL kolesterol diduga melalui mekanisme pengurangan asam lemak bebas dalam plasma yang menyebabkan pengurangan fluks ester kolesterol dari HDL, LDL dan VLDL melalui aktivitas dari kolesterol transfer ester. Rader (2006) mengungkapkan bahwa peningkatan HDL diduga disebabkan karena peningkatan apolipoprotein A yang telah disintesis oleh usus halus dan hati. Selanjutnya apolipoprotein A yang diekskresikan dalam bentuk rendah kolesterol menyatu dengan ATP binding cassette untuk membentuk HDL baru.

\section{Kualitas Air pada Pemeliharaan Udang} Galah (Macrobrachium rosenbergii)

Nilai kisaran kualitas air pada pemeliharaan udang galah dapat dilihat pada Tabel 8.

Tabel 8. Hasil pengukuran kualitas air pemeliharaan udang galah (Macrobrachium rosenbergii)

\begin{tabular}{lcc}
\hline \multicolumn{1}{c}{ Parameter } & Satuan & Kisaran \\
\hline Suhu & ${ }^{\circ} \mathrm{C}$ & $28-29{ }^{\circ} \mathrm{C}$ \\
$\mathrm{pH}$ & - & $6,5-7,5$ \\
Oksigen terlarut & $\mathrm{mg} / \mathrm{l}$ & $6-7$ \\
Amonia & $\mathrm{mg} / \mathrm{l}$ & $0,02-0,75$ \\
\hline
\end{tabular}

Hasil pengukuran suhu pada pemeliharaan udang galah adalah berkisar $28-29{ }^{\circ} \mathrm{C}$. Nilai suhu dalam pemeliharaan udang galah termasuk dalam suhu ideal untuk pertumbuhan. Hal ini sesuai dengan
Sarifin dkk. (2014) yang menyatakan bahwa pemeliharaan udang galah diupayakan pada suhu berkisar antara 24$30{ }^{\circ} \mathrm{C}$.

Menurut Mukti dkk. (2012), pH merupakan suatu ukuran derajat keasaman dengan skala antara satu hingga 14. Hasil pengukuran $\mathrm{pH}$ pada pemeliharaan udang galah adalah 6,5-7,5. Nilai $\mathrm{pH}$ dalam pemeliharaan udang galah termasuk dalam $\mathrm{pH}$ ideal untuk pertumbuhan. Hal ini memenuhi persyaratan kadar $\mathrm{pH}$ yang baik untuk pemeliharaan udang galah sesuai dengan Sarifin dkk. (2014) adalah berkisar antara $6,5-8,5$.

Oksigen terlarut merupakan unsur makronutrien yang sangat penting bagi kelangsungan hidup organisme perairan. (Mukti dkk., 2012). Hasil pengukuran oksigen terlarut pada pemeliharaan udang galah adalah antara 6 - $7 \mathrm{mg} / \mathrm{l}$. Nilai oksigen terlarut ini ideal untuk pertumbuhan udang galah. Hal ini sesuai dengan pernyataan Sarifin dkk. (2014) yang menyatakan bahwa oksigen terlarut pemeliharaan udang galah minimal $3 \mathrm{mg} / \mathrm{L}$.

Amonia merupakan senyawa yang dapat menjadi masalah dalam budidaya ikan (Mahasri dkk., 2012). Nilai amonia pada pemeliharaan udang galah masih aman antara 0,02 - 0,75 mg/l. Hal ini sesuai dengan pernyataan Sarifin dkk. (2014) bahwa nilai amonia dalam pemeliharaan udang galah maksimal $1 \mathrm{mg} / \mathrm{L}$. 


\section{KESIMPULAN DAN SARAN}

1. Pemberian cod liver oil pada pakan komersial berpengaruh terhadap kadar kolesterol total daging udang galah. Pemberian cod liver oil pada dosis $12 \%$ dapat menurunkan kolesterol total dengan kadar terendah dari perlakuan lainnya dengan rata-rata kolesterol $88,3125 \mathrm{mg} / \mathrm{dl}$.

2. Pemberian cod liver oil pada pakan komersial berpengaruh terhadap kadar kolesterol low density lipoprotein (LDL) daging udang galah. Pemberian cod liver oil pada dosis 12\% dapat menurunkan low density lipoprotein (LDL) kadar terendah dari perlakuan lainnya dengan rata-rata $197,72 \mathrm{mg} / \mathrm{dl}$.

3. Pemberian cod liver oil pada pakan komersial berpengaruh terhadap kadar kolesterol high density lipoprotein (HDL) daging udang galah. Pemberian cod liver oil pada dosis $12 \%$ dapat menaikkan high density lipoprotein (HDL) kadar tertinggi dari perlakuan lainnya dengan rata-rata $128,84 \mathrm{mg} / \mathrm{dl}$.

Berdasarkan hasil penelitian penambahan cod liver oil dengan dosis $12 \%$ dari pakan dapat digunakan sebagai penurunan kolesterol udang galah (macrobrachium rosenbergii) untuk mengahasilkan produk budidaya rendah kolesterol dan aman dikonnsumsi.

\section{DAFTAR PUSTAKA}

Arifah. 2006. Peran Lipoprotein dalam Pengangkutan Lemak Tubuh. Jurnal Kaunia Vol II (2) : 122-134.

Ceccaldi, H. J. 1989. Anatomy and Physiology of Digestive Tract of Crustaceans Decapods Reared in Aquaculture.. Advanced in Tropical Aquaculture. Tahiti. Feb 20- March 4. Aquacop. Ifremer, Actes de Colloque pp. 243-259.

Direktorat Jenderal Perikanan Budidaya. 2015. Udang Galah Siratu. www.djpb.kkp.go.id/index. php/export/post/c/287/pdf/. 8 Februari 2016. 2 hal.

Drevon, C. A. 2009. Omega 3 Fatty Acids. Journal Mollers : 1-35.

Emken, E. A., Richard, O. A., S. M. Dulvan and G. J. Nelson. 1999. Effect of dietary docosahexaenoic acid on desaturation and uptake in vivo ofisotope - labeled oleic linoleic, and linolenic acids by male subjects. Journal Lipids 34 (8) : 785-791.

Faradilah, F. 2015. Pengaruh Cod Liver Oil pada Pakan Komersial terhadap Kolesterol, low density lipoprotein (LDL), high density lipoprotein (HDL) Daging Udang Vanamei. Skripsi. Budidaya Perairan. Fakultas Perikanan dan Kelautan. Universitas Airlangga. $\quad 70$ hal.

Lembaga Ilmu Pengetahuan Indonesia Pangan dan Kesehatan. 2009. Kolesterol. UPT Balai Informasi Teknologi LIPI Pangan dan Kesehatan. Jakarta. hal. 1-6.

Puspitasari, A. 2015. Penambahan Asam Amino Esensial Lisin pada Pakan terhadap Laju Pertumbuhan, Efisiensi Pakan dan Kelangsungan 
Hidup Ikan Bawal Air Tawar (Colossoma macropomum). Skripsi. Program Studi Budidaya Perairan. Universitas Airlangga. Surabaya. 60 hal.

Mahasri, G., A. S. Mubarak., M. A. Alamsjah dan A. Manan. 2012. Buku Ajar Manajemen Kualitas Air. Buku Ajar. Fakultas Perikanan dan Kelautan. Universitas Airlangga. Surabaya. hal. 45.

Mukti, T. A., M. Arief dan W. H. Satyantini. 2012. Dasar-Dasar Akuakultur. Buku Ajar. Fakultas Perikanan dan Kelautan. Universitas Airlangga. Surabaya. hal. 35-108.

Rader, D. J. 2006. Molecular Regulation of HDL Metabolism and Function : Implications for Novel Therapies. Journal of Clinical Investigation Vol 116 (12) : 3090-3100.

Ramprasath, V. R., P. J. H. Jones., D. D. Buckley., L. A. Woollett and J. E.
Heubi. 2012. Decreased Plasma Cholesterol Concentrations After PUFA-Rich Diets are not Due to Reduced Cholesterol Absorbtion/Synthesis. Journal Lipids 47 : 1063-1071.

Sarifin, H., K. T. Wibowo., D. Rohmana dan S. Rosellia. 2014. Untung 100 $\%$ dari Budidaya Udang Galah. Agromedia Pustaka. Jakarta. hal. 26.

Stancu, C and A. Sima. 2001. Stains : Mechanism of Action and Effects. Journal Cellular Molecular Medicine Vol 5 (4) : pp 378-387.

Sukarsa, D. R. 2004. Studi Aktivitas Asam Lemak Omega-3 Ikan Laut pada Mencit Sebagai Model Hewan Percobaan. Jurnal Buletin Teknologi Hasil Perikanan VII (1) : 68-79. 